This item was submitted to Loughborough's Research Repository by the author.

Items in Figshare are protected by copyright, with all rights reserved, unless otherwise indicated.

\title{
Maintaining the sanitary border: air transport liberalisation and health security practices at UK regional airports
}

PLEASE CITE THE PUBLISHED VERSION

http://dx.doi.org/10.1111/j.1475-5661.2010.00424.x

\section{PUBLISHER}

Wiley, published on behalf of the Royal Geographical Society (with The Institute of British Geographers) / () The authors

\section{VERSION}

AM (Accepted Manuscript)

\section{LICENCE}

CC BY-NC-ND 4.0

\section{REPOSITORY RECORD}

Budd, Lucy C.S., Morag Bell, and Adam P. Warren. 2019. "Maintaining the Sanitary Border: Air Transport Liberalisation and Health Security Practices at UK Regional Airports". figshare. https://hdl.handle.net/2134/7790. 
This item was submitted to Loughborough's Institutional Repository (https://dspace.lboro.ac.uk/) by the author and is made available under the following Creative Commons Licence conditions.

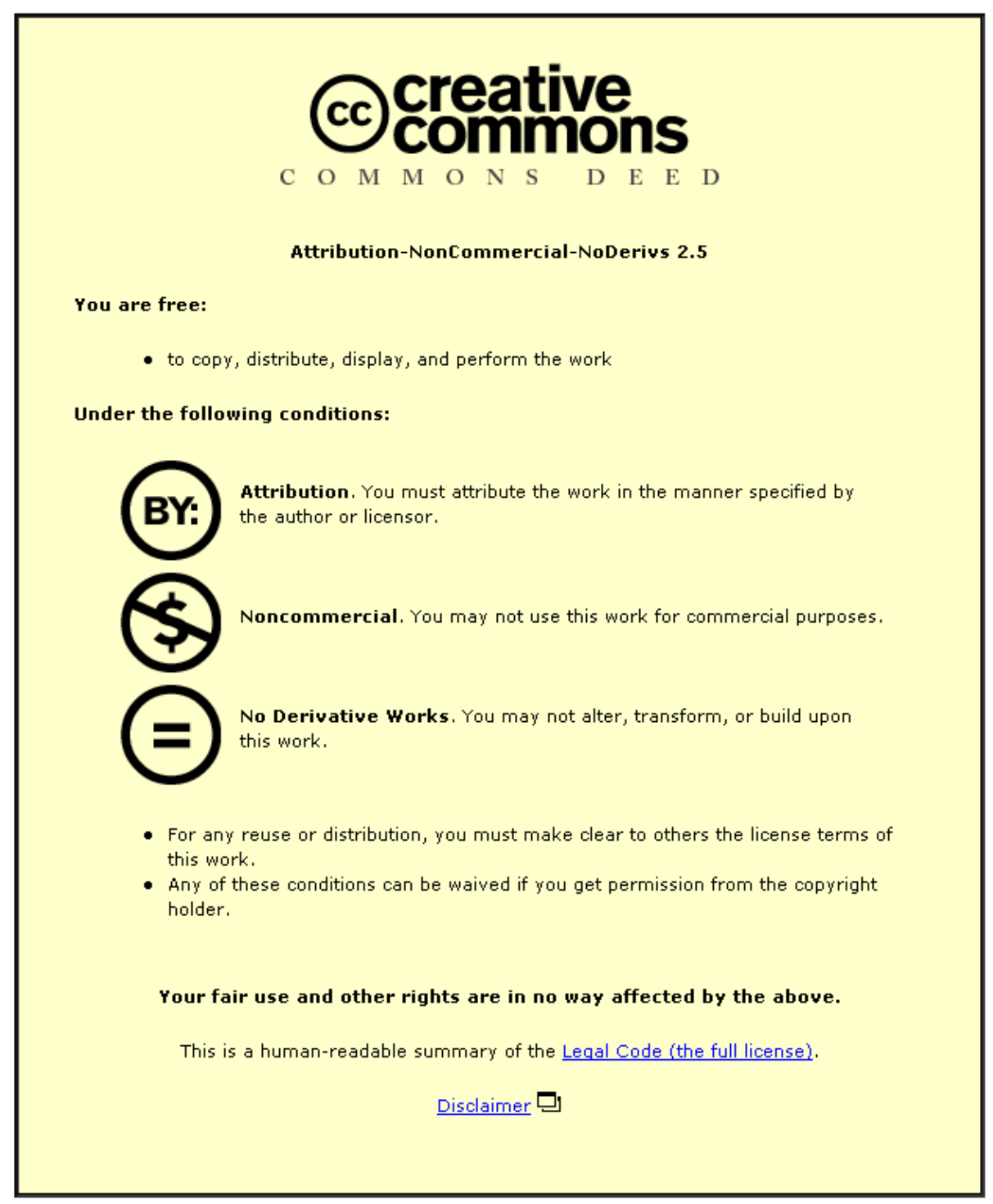

For the full text of this licence, please go to: http://creativecommons.org/licenses/by-nc-nd/2.5/ 


\title{
Maintaining the sanitary border: air transport liberalisation and health security practices at UK regional airports.
}

\begin{abstract}
This paper contributes to ongoing debates surrounding the governance and security of global mobility regimes through a theoretical and empirical examination of the extent to which air transport liberalisation and contemporary practices of infectious disease governance demand a reconceptualisation of national borders. Recent outbreaks of SARS and H1N1 influenza, which spread rapidly around the world via air travel, illustrated the ability of pathogens to disrupt patterns and practices of human mobility and directly led to the introduction of new health screening technologies at airports that were designed to restrict the spread of infection and maintain a sanitary border. Yet while medical specialists have debated the effectiveness of the various screening techniques, and privacy campaigners have expressed concern over some of the technologies that have been deployed in an attempt to intercept these disease threats, there has been no exploration of the extent to which recent regulatory and structural changes within the global aviation industry have exacerbated the challenges of safeguarding public health and simultaneously transformed practices and spatialities of sanitary border control by re-siting national borders within a range of offshore and domestic locations. Drawing on official airport passenger statistics from the UK, this paper contends that, in transforming the spatialities of contemporary patterns of aeromobility, the progressive liberalisation of the commercial aviation sector (and the dramatic rise in passenger numbers, flights, and airports handling international services it effected) - has had unintended and hitherto unexplored consequences for the governance of infectious disease mobility and the material deployment of sovereign sanitary territoriality by creating more points through which an infectious disease may enter or leave a country and moving the border inside UK regions.
\end{abstract}

\section{Introduction}

The outbreak and subsequent worldwide spread, via air travel, of Severe Acute Respiratory Syndrome (SARS) and the H1N1 influenza subtype in 2002-3 and 2009 respectively highlighted global society's continued epidemiological vulnerability to infectious disease. These outbreaks changed the spatialities of global public health governance and stimulated new debates about mobility, pre-emption, sanitary responsibility, and the maintenance of national sovereignty in an apparently 'borderless' and ever-more globalised world. While some scholars have claimed that national sovereignty, the 'bounded territorialisation of power and social relations' (Hudson 1998, 89), is being irrevocably eroded by processes of trans-border travel and exchange, frontier examinations of passengers and goods by immigration, customs, and health officials remain an important structural component of the contemporary global mobility regime (Andraes 2003). However, despite the emergence of a valuable and growing body of literature that addresses particular aspects of aviation security and scrutinises the different practices of border control that are deployed at airports around the world (including the use of biometric passports, advanced electronic travel authorisation software, and visas), relatively little research has explored how the health security interventions that are deployed to try and restrict the mobility of infectious diseases by air have changed the spatialities of border control. While it has long been recognised that air travel is deeply implicated in the international spread of infectious diseases (Royal and 
McCoubrey 1989; Gerard 2002; Pang and Guindon 2004; Mangili and Gendreau 2005; Singer 2005; Bowen and Laroe 2006; Ali and Keil 2006; House of Lords 2007, 2008; Khan et al 2009a, 2009b; Warren et al. 2010), the implications of new practices of sanitary regulation, which were introduced to try and limit the dissemination of human pathogens by air, on practices of border control and biosurveillance have been overlooked. This is not to say that academics have had little to contribute - indeed Ali and Keil's (2010) analysis of the response of Canadian airports to SARS in 2003 alert us to how networked aeromobile flows are increasingly 'secured' at a variety of locations - but rather to suggest that we must build on these existing frameworks to broaden our theoretical repertoire to better equip us to address the moral, ethical, logistical, and financial challenges new and emerging infectious diseases will pose to the territorial integrity of individual states in an age of unprecedented international mobility. Though comparatively unaffected by SARS and H1N1, the UK Government's National Security Strategy of October 2010 identified an influenza-type pandemic as being a 'tier one' priority risk and emphasised the need to respond to new disease threats and minimise their socio-economic impact by first understanding the UK's vulnerability to their importation and then ensuring these vulnerabilities are effectively combated.

Building on research from across the social sciences, transport studies, and epidemiology, this paper contributes to theoretical understandings of territoriality and border control through an empirical examination of the health security interventions that are performed at UK international airports. We show how air travel has changed the spatialities of border control, firstly by permeating the physical limits of a state and localizing the border within sovereign territory and then, more recently (and largely as a result of structural changes within the airline industry) by projecting the national border across UK territory by embedding it in multiple regional airports. At the same time, the growth in international services, combined with rising concern about the global mobility of infectious disease, has prompted many countries, including the UK, to perform new regimes of sanitary pre-emption and biosurveillance on potential travellers overseas. We suggest that the new practices of sanitary regulation we describe have fundamentally changed the relationship between travelling bodies and the state, and require us to re-evaluate our understandings of the interactions between mobility, sanitary pre-emption, and biopolitical governance on a national and an international scale.

The paper begins by reviewing some of the unique geopolitical challenges air travel posed to the territorial integrity of nation-states and highlighting some of the regimes of border control that have been enacted in response. Owing to the paucity of academic research into passenger health security vis-à-vis 'conventional' anti-terrorist security regimes, particular attention is directed to the historical development of international sanitary regulations for air travel and how they are enacted in the UK. In recognition that concepts of biosecurity and biosurveillance are often theorised with respect to borders, we utilise official data on international air passenger movements and route development at UK airports to illustrate how the progressive liberalisation of the European air transport sector during the last two decades has resulted in a dramatic increase in international air traffic, particularly at smaller regional airports that historically handled few (if any) international flights, and how, as a result, the UK border has been re-sited within a range of localities across the UK inside regional airports. The 'opening up' of UK regional airports has had serious implications for practices of health security, biosurveillance, and border maintenance which have not been adequately addressed in extant literature. We comment on how health security regimes and practices of epidemiological pre-emption are increasingly played out in an environment in which air transport liberalisation has expanded opportunities for international mobility but 
heightened the risk of infectious diseases being imported into the UK through multiple entry points. We further suggest that while international public health governance has become grounded in particular localities, the sanitary biosurveillance of individual airline passengers has generated a unique spatiality of sanitary regulation and intervention which often begins before passengers arrive at an airport and may end long after their arrival and subsequent movement into local communities at their place of destination. Though the UK is employed as the principal case study, we contend that our findings are equally applicable to other countries whose air transport markets have been subject to some degree of liberalisation.

\section{Air travel, biosecurity, and the re-spatialisation of national borders}

The development of heavier-than-air powered flight at the beginning of the $20^{\text {th }}$ century transformed practices of international mobility, transborder surveillance, and frontier control. Unlike conventional land-based forms of transport, aircraft were considered to threaten the territorial integrity of nation states as they could overfly existing terrestrial borders with ease (Dargon 1919). In an effort to maintain control over their borders for reasons of defence and national security while simultaneously defending their fledgling civil airline companies from competition, individual nations introduced a raft of aerial navigation acts which defined the specific conditions under which aircraft and air services could operate (Petzinger 1995). The inauguration of regular international passenger services in the early 1920s forced national Governments to confront the fact that a nation's borders were now no longer located at the frontiers of their territory but at any location at which an international flight touched down. Aircraft destabilised traditional understandings of territory and nation and demanded new conceptualisations of national borders. The growth of flying meant it was increasingly apparent that the border was 'not just a line, but a network of ports of entry' that were increasingly located within, as well as on the territorial limits of, states (Salter 2004, 80). However, while some social commentators of the time considered it 'absurd to conceive of air travel and air transport in terms of national borders and local systems of control' (Burney 1929, 142), many countries (the UK included) refused to relinquish control of their borders. Rather, a strict system of bilateral air service agreements was devised, which defined the airports and routes that could be served by particular carriers and the airfares that could be charged. Until the regulations were relaxed (first in the US in the late 1970s and then in Europe and other world markets from the mid-1990s onwards) this strict regulatory regime had the effect of concentrating the majority of international air traffic at one or two key airports.

As Shome (2003) has indicated, the ways in which national borders have been materially deployed in the enactment of sovereign territoriality inevitably produce nuanced geographies of containment and control that function to restrict the movement of certain mobile objects and travelling bodies (and here we would include illegal immigrants, so-called 'health tourists', and convicted criminals) whose transborder mobility is considered undesirable. Within the context of global health security, Wallis and Nerlich (2005) and Nerlich and Halliday (2007) have highlighted the difficulties national governments often face when trying to control the spread of infectious disease across borders. Collier and Lakoff (2008a) have theorised the response to this threat as 'biosecurity'. The concept of biosecurity - a broad title given to technical and political efforts to safeguard human, animal, and plant health at a variety of sites and spatial scales - has emerged as a prominent site of academic enquiry in recent years as researchers seek to understand the various forms of expertise and practices through which particular disease threats are identified, articulated, and managed (Heymann 2003; Collier et al, 2004; Collier and Lakoff, 2008a; Bingham et al, 2008). As subsequent sections of this paper show, the introduction of increasingly stringent national and international sanitary regulations for aviation enabled individual states to exert extra- 
territorial sanitary control over their borders and, as a consequence of the increased biosurveillance these practices entailed, a traveller's journey has come to assume considerable bio-geopolitical significance (Budd et al. 2009) with the 'over there' and 'over here' described by Braun (2007) taking on new and important meanings.

Drawing on the work of surveillance theorists, geographers, amongst others, have begun to explore the implications of global aeromobility for practices of trans-border security and highlight some of the socio-spatial inequities of contemporary air travel. Within this emerging literature, the international airport has been identified as a site in which individual mobile bodies are mapped and different identities ascribed according to predefined assessments of the risks different ages, genders, nationalities, ethnicities, and religious affiliations pose to the safety of the air transport system (Curry 2004; Adey, 2004a, 2004b, 2009; Amoore 2006; Sparke 2006; Salter, 2007; Budd and Adey, 2009). Much of this work has focused on anti-terrorist screening measures (Adey, 2009; Amoore and Hall, 2009) and/or the nature of security regimes that are deployed at airports around the world (Salter, 2007; Bennett, 2008) in an effort to differentiate between 'legitimate' and 'illegitimate' travellers. Flynn (2000), Vaughan-William (in press) and others, have rightly identified how many of the new passenger profiling and data mining techniques that are used to 'sort' passengers are increasingly being performed 'at a distance' before a traveller even arrives at the airport and have commented on the extra-territorial dimension of many modern aviation security protocols. Mark Salter (2004) has spoken of how airline security screening techniques have progressively 'delocalized' the border and moved it 'up stream' in time and place well beyond the physical limits of a state. Vaughan-Williams (in press) has similarly recognised the rise in 'offshore' national bordering practices and how they demand a reconceptualisation of the limits of sovereign territoriality.

Within the context of aviation security, existing advanced electronic passenger pre-screening technologies (including the USA's Electronic System for Travel Authorisation (ESTA) scheme and the UK's 'e-borders' programme) do indeed serve to enhance a nation's spatial and territorial reach well beyond the confines of their national borders by obliging every overseas traveller, who wishes to fly to a country using pre-clearance technology, to share personal information and details about their journey with their airline in advance of their proposed departure time (Dodge and Kitchen 2009). In the UK, the Home Office (2006, 11) has spoken of the need to 'export our borders around the world' to safeguard the territorial integrity of the UK and the UK's 'e-borders' programme uses pre-departure profiling software to assess the threat each of the 200 million annual passenger movements into and out of the UK poses to the UK border and grants or denies individual travellers permission to travel. Evidently, contemporary practices of corporeal border surveillance no longer start or end at an airport but have become increasingly enmeshed in the fabric of everyday life, permeating, via personal computers, the private homes and local communities of all wouldbe travellers. Yet while certain practices of passenger profiling, airport security, and preemption have been widely commented upon within the context of anti-terrorist aviation security discourses, this paper argues that, in the case of infectious disease control, the airport's role as a place of control and containment extends well beyond that of conventional airline security. It has also become more complicated and assumed greater importance within the last twenty years in particular owing to rising numbers of international airline passengers, increased concern about the global mobility of infectious disease, and the development of new sanitary regimes and biosecurity practices of, what Collier and Lakoff (2008b) described with reference to US post-war civil defence as, 'distributed preparedness'. 


\section{The development of sanitary regulations for aviation}

While attempts to control the transborder spread of infectious diseases date back to the use of containment and quarantine methods in the fourteenth century (MacPherson and Gushlak 2001), the development of regular international air travel during the twentieth century prompted the formation of specific sanitary measures for aviation. While the potential for air passengers to carry diseases between countries was first recognised in the early 1920s, it was not until the introduction of regular long-haul passenger services in the 1930s that any coordinated attempts were made to regulate the movements of passengers and cargo to safeguard Western (and, later, global) public health from the threat of infectious diseases being transmitted by air (Budd et al. 2009). The resulting regulations, which stemmed from the First Sanitary Convention for Aerial Navigation of 1933, involved a multiplicity of measures and defined specific approaches for the identification and management of the threats posed by the 'classic' pestilential diseases of cholera, smallpox, yellow fever, plague, and typhus to prevent their spread by air. Many of these measures relied on quasi-scientific or medical interventions that were performed at the airport and/or in aircraft themselves, including quarantine, disinfection, and disinsection (the eradication of insects using chemical pesticides). However, the deployment of such interventions inevitably invoked political, as well as epidemiological, considerations and individual nations often adopted very different prophylactic strategies to try and counter the same biological threats (Baldwin 1999). By the late 1930s, the introduction of progressively faster and larger aircraft, combined with rising numbers of international air travellers and the emergence of new disease threats, had rendered many of the existing practices of frontier disease control largely obsolete and a more up-to-date regime of global disease containment was required.

In 1944, the international community, through the auspices of the recently formed International Civil Aviation Authority (ICAO), attempted to standardise the control of infectious diseases that were known to be transmitted by air through a package of internationally binding measures. Chapter II Article 14 of the 1944 Chicago Convention on Civil Aviation, the document that provided for the post-war development of civil aviation, stipulated that each contracting State must "take effective measures to prevent the spread by means of air navigation of cholera, typhus (epidemic), smallpox, yellow fever, plague, and other communicable diseases” (ICAO 1944). In the same year, the International Sanitary Convention for Aerial Navigation, 1944 (which modified the provisions of the 1933 Convention) called for 'special' (and we would argue pre-emptive) measures 'to prevent the spread by air across frontiers of epidemic or other communicable diseases' (United Nations 1948, 250). Subsequent World Health Organisation (WHO)-mandated International Health Regulations (IHRs), which were introduced during the mid-late twentieth century, sought to provide the maximum security against the international spread of any disease (not just plague, cholera, or yellow fever) that "presents or could present significant harm to humans" (WHO 2005 Article 1) through enhanced regimes of global biosurveillance and control. Van Wagner $(2008,1656)$ suggests the WHO's emphasis on surveillance and coercion is less about protecting the health of citizens and more about 'minimising the effects of disease on the status quo of global capitalism'. The IHR oblige national health authorities to report outbreaks of certain infectious diseases and require Member States to establish protocols to respond to suspected cases of infection among arriving or departing airline passengers and crew. In so doing, the WHO Regulations have changed the spatialities of global public health governance and added new measures for tackling the global spread of infectious disease to the existing health security repertoire. They have also increased the complexity of public health governance in practice and demanded heightened inter-agency collaboration. 
The legal provision and the practical delivery of health security at UK airports rests with a multitude of different organisations including international regulators (e.g. ICAO, the International Civil Aviation Organisation, and the WHO), national public health agencies, local authorities, and private enterprises. These organisations interact through a complex web of interrelationships. In the UK, the Department of Health in England and the devolved administrations in Northern Ireland, Scotland, and Wales are responsible for transposing the requirements of the IHR (as originally promulgated in 1969 and revised in 2005) into national law. In England, specific powers for applying health controls on aircraft and at airports are contained within three separate acts; the Public Health (Aircraft) Regulations 1979, the Public Health (Control of Disease) Act 1984, and the Public Health (Aircraft) (Amendment) (England) Regulations 2007. Collectively, these Acts are often referred to as the Port Health Regulations (PHR). Similar legislation exists or is planned for the devolved administrations. The PHR enable measures to be taken at airports against both arriving and departing passengers and aircrew to limit any potential danger to public health and reduce the spread of infectious disease. These measures include the medical examination of potential entrants to the UK, the grounding of aircraft and, if required, the detention of passengers, crew, cargo, and equipment until local medical authorities are satisfied that no disease threat exists (HPA 2006).

The main statutory responsibility for implementing the Port Health Regulations at UK (air)ports and international railway stations rests with the Local Authority in which the facility is sited (some local authorities in areas of heightened transportation activity are specifically designated as 'Port Health Authorities') (see Hawker et al 2005). These Local Authorities are responsible for overseeing the local administration and maintenance of a sanitary border as defined by national and international law. The daily practice of airport health security, however, involves a complex collaboration between local police, medical practitioners, environmental health officers, airline and airport staff, local Primary Care Trusts (a division of the National Health Service in England that provides some primary and/or community healthcare services), and national security, immigration, and health services (including, but not limited to, private security contractors, the UK Border Agency, the British Transport Police, and the UK's Health Protection Agency) (HPA 2006). This institutional and legislative framework is further complicated by the fact that different agencies discharge their responsibilities in different ways at different airports according to the physical limitations and operational characteristics of the individual airports concerned (see Budd et al, in press).

\section{Regulating aeromobile bodies: public health interventions at UK airports}

At the time of their introduction in the 1930s, the relatively small number of long-haul air travellers and the limited number of UK airports with international services meant that it was comparatively easy for airlines, airport officials, and immigration/customs officers to comply with sanitary regulations, but as the numbers of passengers and airports offering international services grew during the late twentieth century, such intensive biosurveillance and policing of individual travellers became increasingly impractical. As a result, contemporary practices of airport health security screening increasingly rely on targeted checks of particular mobile populations (Gushulak and MacPherson 2000; Welshman 2006; Major 2008).

Public pressure to introduce compulsory Port of Entry medical examinations of particular groups of would-be entrants to the UK was first exerted in the late 1950s to check for symptoms of tuberculosis (Welshman and Bashford 2006). It subsequently became national policy to refer any prospective entrant for medical checks who was seeking entry for six months or more; appeared unwell; claimed asylum; or originated in a country that is 
considered to be high-risk for tuberculosis (Hardie and Watson 1993). In 1962, the Commonwealth Immigrants Act empowered immigration officers and Port Health Authorities to refer certain categories of traveller to medical inspectors for examination on arrival at the UK border and, in February 1965, chest x-rays were introduced on an experimental basis at London's Heathrow Airport (Welshman and Bashford 2006). At this time, virtually all long-haul air traffic arrived at the west London airport and there was little need for port health screening at other sites. However, the recent inauguration of regular long-haul flights at UK regional airports has effectively re-sited or 'localized' the border both across and within UK territory. This has meant that the equipment, staff, and resources that are required to screen travellers who either arrive from 'high-risk' disease areas or are departing to particular countries that require health checks to be performed at the point of embarkation may not always be available. Moreover, we suggest that while it is relatively easy for immigration officers to identify passengers arriving on direct flights from particular destinations, there are no mechanisms through which passengers who may have originated in a high-risk country but transited through an intermediate hub can be identified. Hence, a body originating in a known endemic disease area can, simply by virtue of its route through the global airline network, enter the UK without additional health checks (Budd et al. in press). As Horner $(1974,101)$ astutely remarked, 'the degree of health surveillance is determined not by medical need but by the capriciousness of the route into the country selected by the traveller himself'. Hence, a traveller originating in endemic disease area can arrive at a UK airport, ostensibly from Europe, having merely changed planes at an intermediate hub.

At the time of writing, routine health checks at UK airports are only conducted on specific groups of aeromobile travellers whose destination, nationality, or country of departure is considered to represent a heightened epidemiological risk. On services from the UK to certain destinations, for example, check-in staff must invoke formal pre-departure screening protocols that are demanded by the country of destination to ensure that all passengers have received an approved form of chemoprophylaxis and possess valid vaccination certificates for their destination prior to travel. Indeed the airline is at risk of incurring a fine for transporting any passenger who does not. Equally, particular categories of would-be entrants to the UK may be subject to health checks before travelling, on arrival at the UK border, and after entry to the UK. Biosecurity is thus a highly selective process and a traveller's national identity becomes crucial in determining whether additional biosurveillance measures will be targeted at them and the location in which those measures will be applied. For some prospective long-term migrants to the UK, for example, a clear chest $\mathrm{x}$-ray, conducted in their country of citizenship, is now a precondition of applying for a UK visa. While some of health interventions are performed 'at a distance' overseas, other passengers, by virtue of their nationality, their flight's origin, or by displaying suspected symptoms of infection, may also be intercepted at the UK border on arrival.

Under the 1971 Immigration Act, UK immigration officers are empowered to refer prospective migrants (who are subject to immigration control) for medical examination by a dedicated Port Medical Inspector (PMI) before being granted permission to enter the UK. In light of a PMI's findings, an immigration officer can, in principle, refuse a potential applicant entry to the UK on public health grounds. Other applicants, who are granted permission to enter the UK, may subsequently be invited to attend follow-up medical appointments in local hospitals to safeguard both their health and the wellbeing of the wider community (Welshman 2006). Though it has rarely been considered in such terms, in the context of health security the UK border is evidently flexible across time and space, variously manifesting itself in selected countries overseas many weeks prior to departure, at overseas 
airports, in aircraft cabins, at UK airports, and in the local communities into which travellers disperse. Though rarely considered in such terms, recent regulatory and structural changes within the airline industry have undoubtedly exacerbated the complexities of maintaining the UK’s sanitary border by ‘opening up’ regional airports to long haul services.

\section{Air transport liberalisation and the reframing of UK sanitary borders}

The progressive liberalisation of the European air transport market through three packages of measures during the 1990s opened up the continent's airports and airways to effective competition for the first time and resulted in an unprecedented demand for air travel. The newly liberalised operating environment allowed new airlines to enter the marketplace and enabled aircraft and airport operators to engage in effective competition for the first time.

Liberalisation lifted capacity constraints and removed restrictions on airport access. It also dissolved traditional bilateral and multilateral air service agreements that stipulated which airlines could fly individual routes, the frequency with which the services could operate, the airports that could be served, and the airfares that could be charged (Goetz and Graham 2004). The resulting emergence and expansion of low-cost airlines, and the reaction of incumbent carriers and airports to their arrival, has been extensively documented, with numerous scholars charting the changing pattern of service provision that has been produced as a consequence (see, for example, Dobruszkes 2006). However, while much has been written about the rise of low-cost flying and the remodelling of the airport/airline relationship liberalisation engendered (Humphreys 1999; Lawton 2002; Francis et al 2004), an unintended consequence of the sudden 'opening up' of regional airports to regular long-haul services was a dramatic increase in the number of sites through which potentially infected travellers and unwanted pathogens could enter or leave a country.

The increased supply of international flights at regional airports has been both a driver of, and driven by, increased demand for trade and tourism, immigration, and the internationalisation of the labour market (CAA 2009). Since the mid 1980s, the number of airline passengers worldwide has doubled to the point where in excess of 2.1 billion people boarded a scheduled flight in 2006 (IATA 2007). In the UK, total international passenger traffic at all UK airports grew from 42.9 million passengers in 1980 to 189.1 million in 1998 while traffic at regional airports increased from 8.4 million to 65.8 million (35\% of the total) in the same time period (CAA 2007; 2008a; 2008b). In 2005, UK residents made over 66.4 million trips aboard and over 30 million international tourist arrivals were recorded (HPA 2007). While much of this traffic occurred between the UK and other European Union countries, the number of visits to/from long haul destinations increased by over a third between 2003 and 2005 (ibid. 2007). Crucially, however, it is not simply the volume of international mobility that is significant, but the number of UK airports that are supporting international services. In 1990, fewer than 100 scheduled international destinations were served from UK regional airports ${ }^{1}$, but by 2006 the figure had increased to over 400 (CAA 2007). An indication of the growth of international scheduled services from selected UK regional airports is provided in Table I. Particularly significant growth occurred at Liverpool (up from one international scheduled service in 1990 to 25 in 2006), Bristol (whose portfolio of international services increased five-fold in the same time period), and East Midlands (up from three in 1990 to 17 in 2006), owing, in no small part, to the inauguration and subsequent expansion of low-cost services.

*** TABLE I ABOUT HERE ***

\footnotetext{
${ }^{1}$ Taken here to mean all airports except London Heathrow and London Gatwick.
} 
While the majority of international flights at regional airports are short-haul European services, many sites also now support a significant number of long-haul 'spoke', or feeder, services to airports in the eastern USA, the Middle East (principally Dubai), and the Indian subcontinent. At the time of writing, the only world regions with no direct flights to UK regional airports are Australasia and Central and Southern Africa, while 47\% and 37\% respectively of the UK's total passenger traffic to Central America and North Africa originates from regional airports (Table II). The increased global connectivity of UK regional airport has not only impacted on trade, tourism, and inward investment, but also brought endemic disease foci into UK regions, some of which may not have the facilities to adequately identify or prevent the spread of infection.

\section{*** TABLE II ABOUT HERE ***}

The progressive retraction of UK domestic services to/from London Heathrow during the last decade, combined with the opening up of regional airports, has enabled foreign carriers to exploit the frustrated demand for long-haul scheduled services from UK regional airports by establishing 'spoke' services to their foreign hubs. Between 1990 and 2006, the number of UK regional airports served directly from Heathrow declined from 18 to nine while the number with a direct connection to Amsterdam increased from 15 to 19 (CAA 2007). UK regional airports have also become increasingly well connected to Paris and Air France's worldwide network of more than 600 destinations, with at least one daily service to Paris operating from 13 regional airports (Air France 2009). Elsewhere, Emirates and Continental Airlines, two of the most significant foreign carriers operating at UK regional airports in terms of total passenger numbers, both transported nearly one million travellers between UK regional airports and their respective hubs in Dubai and New York in 2006 (Table III).

\section{*** TABLE III ABOUT HERE ***}

Crucially, from a public health perspective, these flights do not simply serve the hub airports themselves, but a multitude of places beyond. On any given flight, it has been estimated that $50-90 \%$ of passengers will be transiting to destinations elsewhere (CAA, 2007) and the growing number of transfer passengers undoubtedly has significant implications for public health provision and border control at UK regional airports by obfuscating the geographical complexities of individual journeys. Such a spatial transformation in the pattern of air service provision in the UK underpins our contention that air transport liberalisation (and the associated 'opening up' of regional airports to international air services) has fundamentally altered the spatiality of Port Health provision in the UK and compounded the challenges of discharging effective health security safeguards at every (new) point of entry into the UK. While data protection and patient confidentiality protocols prevent the release of hospital admission statistics that may (dis)prove a causal link between the opening up of regional airports to long-haul services and an increased incidence of infectious disease, evidence from overseas (Khan et al 2009a, 2009b) and the rapid local health security response that was invoked at Birmingham International Airport in the West Midlands to the arrival of charter flights from Mexico at the beginning of the H1N1 outbreak in April 2009 suggests that the threat of infectious diseases being brought into the country through regional airports is taken seriously (Collins 2009).

\section{Discussion and Conclusion}

Following recent outbreaks of human infectious diseases across the world, including SARS and influenza A subtypes, the epidemiological risks associated with mass international aeromobility are now a focus of heightened concern among global health agencies and many 
national governments. The emergence of these new threats has also prompted a number of scholars to examine the implications for global health security and to theorise the response in terms of 'biosecurity'. This body of literature has highlighted the extension of the sanitary border to locations 'over there' and commented on the nature of new biosurveillance practices at airports and their implications for individual passenger journeys. However, no research has explored the ways in which air transport liberalisation and, more particularly, the development of international air services at multiple UK regional airports, is reshaping practices of passenger health security and regimes of sanitary border control.

Drawing on an historical analysis and empirical evidence of contemporary health security practices and changing patterns of passenger aeromobility in the UK, this paper has demonstrated how health security regimes and practices of epidemiological pre-emption are increasingly played out in an environment in which air transport liberalisation has expanded opportunities for international mobility on the one hand, and simultaneously increased the range of localities through which infectious diseases can be transmitted. It has shown how the liberalisation of European air travel and the emergence of new disease threats have changed the nature and location of practices sanitary border control. Within the context of debates about globalisation, a 'borderless' world and the 'liberated' aeromobile traveller, our evidence prompts a reconsideration of concepts of territoriality and border control.

Granted, historical investigation indicates that the concept of sanitary pre-emption at UK airports is not new. Indeed there has been a dedicated Health Control Unit at London Heathrow since 1947 to deal with the health risks posed by international aeromobility. However, it is apparent that the contemporary sanitary biosurveillance of individual airline passengers is generating unique spatialities of sanitary regulation, pre-emption, and intervention which often begin before passengers arrive at an airport and may end long after arrival at their final destinations. These distinctive mobilities associated with biosecurity are rendered more complex by the recent introduction of regular long-haul international flights at multiple regional airports in the UK. The theoretical and practical implications of these new patterns of aeromobility are significant. These mobilities require us to reframe biosecurity not only in terms of sanitary border control 'offshore' but also, and more particularly, 'within' a state. Owing to the growth of commercial air travel, borders are increasingly being extended across sovereign space to nodes within national territories beyond the major international airports. They are also entering the localities within which these airports are located.

In the UK, the emergence of regional airports as part of a network of ports of entry and exit for international travel have brought the sanitary border into the heart of UK national territory. In terms of authority and responsibility, some local authorities, simply by virtue of having an airport located within their administrative boundaries, have rapidly had to assume a Port Health function for which they often had no prior experience. Equally, many of the primary healthcare agencies involved in responding to the epidemiological challenges of aeromobility are not directly associated with international air travel per se. Furthermore, it has been suggested that a certain degree of professional and/or territorial competition may exist between agencies involved in Port Health provision and an unwillingness to pay for interventions that are considered to be another agency's responsibility. Consequently, instead of being preoccupied by the threat of infectious disease 'out there', we need to be aware of the weaknesses inherent in the UK's existing regime of sanitary preparedness. At the very least, we must recognise that the UK is arguably as much an exporter as an importer of disease and be alert to the distinctive spatial and temporal dimensions of modern transportation networks, disease outbreaks, and regimes of sanitary governance. 
Clearly, frontier examinations of passengers and aircrew are insufficient when dealing with the volume and complexity of the contemporary patterns of aeromobility that we have uncovered. However, the introduction of new regimes of sanitary border control 'offshore', at the frontier, and within nation states, and the associated grounding of international public health governance in an extended range of localities, raises significant practical, financial, and ethical challenges, which, in turn, raise complex questions about the nature of distributed sanitary preparedness. Rather than merely emphasising the 'offshore' or extraterritorial dimension of modern aviation sanitary protocols and practices of pre-emption, we argue that the maintenance of a sanitary border involves a multiplicity of time-spaces that operate both within and beyond the territorial limits of a state and we call for a more nuanced understanding of the border within states. It can be argued that, paradoxically for the 'liberated' traveller, intrusive practices of screening and policing represent a return to the very exclusionary notions of 'inside' and 'outside' that the more liberalised regimes of crossborder mobility control were designed to overcome. Crucially, these practices are now experienced at multiple sites in a range of new localities, many of which were conventionally remote from the rigours of frontier border control. The operation of this new 'inside' is, as the organisational and territorial tensions that exist between agencies involved in Port Health provision clearly demonstrate, highly complex. Such theoretical reflection on the border within should enable us to better identify and repair vulnerabilities in the sanitary border regimes of countries like the UK and, in so doing, help protect the health and well-being of travelling and non-travelling populations both within and beyond individual states.

\section{Acknowledgements}

We are grateful to the three anonymous referees whose insightful comments enabled us to strengthen our paper.

\section{References}

Adey P 2004a Secured and sorted mobilities: examples from the airport Surveillance and Society 1 500-519

Adey $\mathbf{P}$ 2004b Surveillance at the airport: surveilling mobility/mobilising surveillance Environment and Planning A 36 1365-1380

Adey P 2009 Facing airport security: affect, biopolitics, and the preemptive securitisation of the mobile body Environment and Planning D: Society and Space 27(2) 274-295

Air France 2009 Corporate website www.airfrance.com Last accessed 20/03/2009

Ali S H and Keil R 2006 Global cities and the spread of infectious disease: the case of severe acute respiratory syndrome (SARS) in Toronto, Canada Urban Studies 43 491-509

Ali S H and Keil R 2010 Securitizing networked flows: Infectious Diseases and airports In: Graham S (Ed.) Disrupted Cities: When Infrastructure Fails New York, Routledge

Amoore L 2006 Biometric borders: Governing mobilities in the war on terror Political Geography 25 336-351 
Amoore L and Hall A 2009 Taking people apart: digitised dissection and the body at the border Environment and Planning D: Society and Space 27 444-464

Andraes P 2003 Redrawing the line: Borders and Security in the $21^{\text {st }}$ century International Security 28(2) 78-111

Baldwin P 1999 Contagion and the state in Europe, 1830-1930 Cambridge, University Press.

Bennett C J 2008 Mobilities and modulations: the airport as a difference machine. In: Salter, M. (ed) Politics at the Airport, University of Minnesota Press, Minneapolis 51-76

Bingham N, Enticott G and Hinchliffe S 2008 Biosecurity: spaces, practices, and boundaries. Environment and Planning A 40(7) 1528-1533

Bowen J T and Laroe C 2006 Airline networks and the international diffusion of severe acute respiratory syndrome (SARS) The Geographical Journal 172(2) 130-144

Braun B 2007 Biopolitics and the molecularization of life Cultural Geographies 14 6-28

Budd L and Adey P 2009 The software-simulated airworld: anticipatory code and affective aeromobilities Environment and Planning A 41 1366-1385

Budd L, Bell M and Brown T 2009 Of plagues, planes and politics: controlling the global spread of infectious diseases by air Political Geography 28 426-435

Budd L, Warren A, and Bell M (in press) Safeguarding Public Health at UK Airports: An Examination of Current Health Security Practices Transportation Planning and Technology

Burney C D 1929 The World, the Air, the Future London, George Allen and Unwin

Civil Aviation Authority 2007 Air Services at UK Regional Airports. An Update on Developments. Economic Regulation Group CAP 775 London, CAA

Civil Aviation Authority 2008a Summary of Activity at Reporting Airports, 2008. http://www.caa.co.uk/docs/80/airport_data/2008Annual/Table_02_2_Summary_Of_Activity _at_UK_Airports_2008.pdf

Civil Aviation Authority 2008b International Air Passenger Route Analysis, 2008. http://www.caa.co.uk/docs/80/airport_data/2008Annual/Table_12_1_Intl_Air_Pax_Route_A nalysis_2008.pdf

Civil Aviation Authority 2009 International Relations. The growth of air travel to visit friends and relatives March London, CAA

Collier S, Lakoff A, and Rabinow P 2004 Biosecurity: towards an anthropology of the contemporary Antropology Today 20(5) 3-7

Collier S and Lakoff A 2008a The problem of securing health. In: Lakoff, A., Collier, S. (eds) Biosecurity Interventions. Columbia University Press, New York 7-32 
Collier S and Lakoff A 2008b Distributed preparedness: the spatial logic of domestic security in the United States Environment and Planning D 26(1) 7-28

Collins T 2009 Birmingham Airport on alert as flight arrives from Mexico. Birmingham Post 05/04/2009 Retrieved from www.birminghampost.net/news on 25/03/2010

Curry M R 2004 The Profiler's Question and the Treacherous Traveler: Narratives of Belongin in Commercial Aviation Surveillance and Society 1(4) 475-499

Dargon J 1919 The Future of Aviation (Translated P Nutt) London, David Nutt

Dobruszkes F 2006 An analysis of European low cost airlines and their networks. Journal of Transport Geography 14(4) 249-264

Flynn S E 2000 Beyond Border Control Foreign Affairs 79(6) 57-68

Francis G, Humphreys I, and Ison S 2004 Airports' perspectives on the growth of low cost airlines and the remodelling of the airport-airline relationship Tourism Management 25(4) 507-514

Gerard E 2002 Infectious disease in air travellers arriving in the UK. Journal of the Royal Society of the Promotion of Health 122(2) 86-88

Goetz A R, and Graham B 2004 Air transport globalization, liberalization and sustainability: post-2001 policy dynamics in the United States and Europe. Journal of Transport Geography 12(4) 265-276

Graham B, and Guyer C 2000 The role of regional airports and air services in the United Kingdom. Journal of Transport Geography 8(4) 249-262

Gushulak B D and MacPherson D W 2000 Population Mobility and Infectious Diseases: The Diminishing Impact of Classical Infectious Diseases and New Approaches for the $21^{\text {st }}$ Century Clinical Infectious Diseases 31 776-780

Hardie R M and Watson J M 1993 Screening migrants at risk of tuberculosis British Medical Journal 307 1539-1540

Hawker J, Begg N, Blair I, Reintjes R, Weinberg J 2005 Communicable Disease Control Handbook Wiley, Blackwell.

Health Protection Agency 2006 Health Activity Relating to People at Ports, Airports, and international train stations in England London, HPA

Health Protection Agency 2007 Foreign-travel associated illness England, Wales and Northern Ireland - 2007 Report London, Health Protection Agency.

Heymann D L 2003 The Evolving Infectious Disease Threat: implications for national and global security Journal of Human Development 4(2) 191-207

H M Government 2010 A Strong Britain in an Age of Uncertainty: The National Security Strategy London, HMSO 
Home Office 2006 Borders, Immigration, and Identity Action Plan: Using the national Identity Scheme to Strengthen our Borders and Enforce Compliance within the UK December London, The Stationery Office

Horner J S 1974 Port Health Control British Medical Journal $13^{\text {th }}$ July 1974 101-104

House of Lords 2007 Air Travel and Health: an Update. House of Lords Science and Technology Committee. HL Paper 7. London, HMSO

House of Lords 2008 Diseases Know no Frontiers: How Effective are Intergovernmental Organisation in Controlling their Spread? House of Lords Select Committee on Intergovernmental Organisations Volume 1: Report. HL Paper 143-1 London, HMSO

Hudson A 1998 Beyond the borders: globalisation, sovereignty and extra-territoriality Geopolitics 3(1) 89-105

Humphreys I 1999 Privatisation and commercialisation. Changes in UK airport ownership patterns Journal of Transport Geography 121-134.

IATA 2007 IATA Economic Briefing: passenger and freight forecasts 2007-2011 Retrieved from www.iata.org on 11/10/08

International Civil Aviation Organisation 1944 Convention on International Civil Aviation Done at Chicago on the $7^{\text {th }}$ Day of December 1944 Chicago, ICAO

Khan K, Arino J, Calderon F, Chan A, Gardam M, Heidebrecht C, Hu W, Janes D, MacDonald M, Sears J, Raposo R and Wang S 2009a An Analysis of Canada's Vulnerability to Emerging Infectious Disease Threats via the Global Airline Transport network The Centre for Research on Inner City Health, St Michael's Hospital, Toronto. Retrieved from www.biodiaspora.com on 25/03/2010

Khan K, Arino J, Hu W, Raposo R, Sears J, Calderon F, Heidebrecht C, MacDonald M, Liauw J, Chan A, and Gardam M 2009b Spread of Novel Influenza A (H1N1) Virus Via Global Airline Transportation New England Journal of Medicine 361(2) July 9, 212-214

Kitchin R and Dodge 2009 Airport code/spaces in Cwerner S, Kesselring S and Urry J (Eds.) Aeromobilities London, Routledge, 96-114

Lawton T 2002 Cleared for Take-Off. Structure and Strategy in the Low-Fare Airline Business Aldershot, Ashgate

MacPherson D W and Gushlak B D 2001 Human Mobility and Population Health: New approaches in a globalising world Perspectives in Biology and Medicine 44(3) 390-401

Major C 2008 Affect work and infected bodies: biosecurity in an age of emerging infectious disease Environment and Planning A 40(7) 1633-1646

Mangili A and Gendreau M A 2005 Transmission of infectious diseases during commercial air travel. The Lancet 365(12) 989-996 
Nerlich B and Halliday C 2007 Avian flu: the creation of expectations in the interplay between science and the media. Sociology of Health and Illness 29 (1), 46-65

O’Byrne D J 2001 On passports and border controls Annals of Tourism Research 28(2) 399416.

Pang T and Guindon E 2004 Globalisation and risks to health European Molecular Biology Organization Reports Vol.5 Special Issue Science and Society S11-S16

Petzinger T 1995 Hard Landing How the Epic Contest for Power and Profits Plunged the Airlines into Chaos London, Aurum

Royal L and McCoubrey I 1989 International spread of disease by air travel American Family Physician 40(5) 129-136

Shome R 2003 Space Matters: The Power and Practice of Space Communication Theory 13(1) 39-56

Salter M 2004 Passports, Mobility, and Security: How smart can the border be? International Studies Perspectives 5 71-91

Salter M 2007 Governmentalities of an airport: heterotopia and confession. International Political Sociology 1, 49-66

Singer D A 2005 Transmission of infections during commercial air travel The Lancet 365 2176-2177

Sparke M B 2006 A neoliberal nexus: Economy, security, and the biopolitics of citizenship on the border Political Geography 25 151-180

United Nations - Treaty Series 1061948 Sanitary Convention for Aerial Navigation, 1944, modifying the International Sanitary Convention for Aerial Navigation of 12 April 1933 Opened for signature at Washington, on 15 December 1944

Van Wagner E 2008 The practice of biosecurity in Canada: public health legal preparedness and Toronto’s SARS crisis Environment and Planning A 40 1647-1663

Vaughan-Williams $\mathbf{N}$ in press The UK border security continuum: virtual biopolitics and the simulation of the sovereign ban Environment and Planning D

Wallis P and Nerlich B 2005 Disease metaphors in new epidemics: the UK media framing of the 2003 SARS epidemic. Social Science and Medicine 60, 2629-2639

Warren A, Bell M, and Budd L 2010 Airports, localities and disease: representations of global travel during the H1N1 pandemic Health and Place 16(4) 727-735

Welshman J 2006 Compulsion, Localism, and Pragmatism: The Micro-Politics of Tuberculosis Screening in the United Kingdom, 1950-1065. Social History of Medicine 19(2) 295-312 
Welshman J, and Bashford A 2006 Tuberculosis, migration, and medical examination: lessons from history Journal of Epidemiology and Community Health 60 282-284

World Health Organization 2005 WHA 58.3 Revision of the International Health Regulations Geneva, WHO 
Table I: Growth in international scheduled destinations from selected UK regional airports, 1990-2006

\begin{tabular}{llllll}
\hline Airport & 1990 & 1996 & 2002 & 2004 & 2006 \\
\hline Birmingham & 13 & 19 & 29 & 34 & 35 \\
Bristol & 5 & 4 & 13 & 17 & 25 \\
East Midlands & 3 & 4 & 11 & 14 & 17 \\
Edinburgh & 3 & 5 & 6 & 9 & 16 \\
Liverpool & 1 & 1 & 9 & 12 & 25 \\
Manchester & 15 & 29 & 43 & 60 & 57 \\
Newcastle & 4 & 7 & 6 & 11 & 14 \\
\hline
\end{tabular}

Source: derived from CAA (2007)

Table II: Total passenger traffic by world region, 2008

\begin{tabular}{lllll}
\hline Region & All airports & $\begin{array}{l}\text { London } \\
\text { airports }\end{array}$ & $\begin{array}{l}\text { Regional } \\
\text { airports }\end{array}$ & $\begin{array}{l}\text { Regional share } \\
\text { of total (\%) }\end{array}$ \\
\hline Australasia & $1,637,146$ & $1,637,146$ & 0 & 0 \\
Caribbean & $1,947,174$ & $1,588,127$ & 359,047 & 18 \\
Central America & $1,380,256$ & 737,994 & 642,262 & 47 \\
South America & 414,798 & 408,432 & 6,366 & 2 \\
North America & $21,673,661$ & $18,614,551$ & $3,059,110$ & 14 \\
Western Europe (EU) & $112,463,240$ & $62,821,212$ & $49,642,028$ & 44 \\
Western Europe (Other) & $12,894,393$ & $8,614,426$ & $4,279,967$ & 33 \\
Eastern Europe (EU) & $11,111,086$ & $7,182,246$ & $3,928,840$ & 35 \\
Eastern Europe (Other) & $1,294,036$ & $1,202,189$ & 91,847 & 7 \\
Indian sub continent & $3,968,551$ & $3,388,018$ & 580,533 & 15 \\
Middle East & $6,110,738$ & $4,514,755$ & $1,595,983$ & 26 \\
Near East & $1,219,483$ & $1,164,158$ & 55,325 & 5 \\
Far East & $5,838,931$ & $5,657,915$ & 181,016 & 3 \\
North Africa & $3,640,732$ & $2,297,596$ & $1,343,136$ & 37 \\
West Africa & $1,121,687$ & $1,039,200$ & 82,487 & 7 \\
Central Africa & 65,887 & 65,887 & 0 & 0 \\
East Africa & 719,676 & 706,752 & 12,924 & 2 \\
Southern Africa & $1,613,770$ & $1,613,770$ & 0 & 0 \\
\hline Total & $\mathbf{1 8 9 , 1 1 5 , 2 4 5}$ & $\mathbf{1 2 3 , 2 5 4 , 3 7 4}$ & $\mathbf{6 5 , 8 6 0 , 8 7 1}$ & $\mathbf{3 5}$ \\
\hline Sotal & & & & \\
\hline
\end{tabular}

Source: derived from CAA 2008b

Table III: Total passenger traffic on services to New York and Dubai from UK regional airports, 2008

\begin{tabular}{|c|c|c|c|}
\hline \multicolumn{2}{|c|}{ Services to New York (Newark) } & \multicolumn{2}{|c|}{ Services to Dubai } \\
\hline From & Passengers & From & Passengers \\
\hline Belfast & 99,714 & Birmingham & 395,194 \\
\hline Birmingham & 106,324 & Glasgow & 240,677 \\
\hline Bristol & 90,159 & Manchester & 491,982 \\
\hline Edinburgh & 156,039 & Newcastle & 140,954 \\
\hline Glasgow & 110,960 & & \\
\hline Manchester & 216,256 & & \\
\hline
\end{tabular}

